\title{
Travel Behavior Changes after COVID-19 Outbreak in Taiwan
}

\author{
Rong-Chang Jou $\mathbb{D}$, Chen-Siang Yeh, and Ke-Hong Chen $\mathbb{D}$ \\ Department of Civil Engineering, National Chi Nan International University, Nantou 54561, Taiwan \\ Correspondence should be addressed to Rong-Chang Jou; rcjou@ncnu.edu.tw
}

Received 2 June 2021; Accepted 13 January 2022; Published 11 February 2022

Academic Editor: Mehdi Nourinejad

Copyright ( $\odot 2022$ Rong-Chang Jou et al. This is an open access article distributed under the Creative Commons Attribution License, which permits unrestricted use, distribution, and reproduction in any medium, provided the original work is properly cited.

\begin{abstract}
Although the coronavirus disease (COVID-19) has been under control in Taiwan, the accumulated number of confirmed patients has reached up to 14,853 , where 661 cases were fatal with a fatality rate of $4.45 \%$ (since the virus outbreak until July 1,2021 ). Globally, the toll of confirmed cases has reached 182,641,391 people, where 3,955,679 cases were fatal with a fatality rate of $2.17 \%$ (from the virus outbreak until July 1, 2021). Considering the disease has not been under control yet and IT still significantly influences people's daily travel behavior worldwide, it is urgent to investigate as to what extent it changes people's travel habits. Therefore, we conducted a survey from April 24 to May 2, 2020, to obtain data on Taiwanese people's travel behavior before and after the outbreak of COVID-19. Two models, logistic regression and ordered logit models, were used. As for the models' performance, the estimated thresholds of the ordered logit model are significantly positive, and its coefficient is smaller than that of the logistic model, indicating that the estimated coefficients would be overestimated if the dependent variable is dichotomous. Hence, this study suggests that the influence of COVID-19 on travel behaviors in Taiwan can be explained by the ordered logit models. Several important conclusions are described as follows. First, people might significantly reduce travel activities related to social entertainment during the pandemic outbreak. Second, the total travel activities by private vehicles are significantly reduced, while there is no significant decrease in the use of transit. Finally, the important explanatory variables included the importance of the time to promote government policies (such as implementing the real-name registration system for mask purchases, publishing confirmed cases, and establishing the transit disinfection system), types and number of weekly activities, and storage of various types of consumer goods. The results of our study can serve as an important reference for accommodating similar scales of pandemics occurring in the future.
\end{abstract}

\section{Introduction}

Although the coronavirus disease (COVID-19) has been under control in Taiwan, and social and commercial activities are steadily recovering, the accumulated number of confirmed patients has reached up to 14,853 , where 661 cases were fatal with a fatality rate of $4.45 \%$ (since the virus outbreak until July 1, 2021). Globally, the toll of confirmed cases has reached 182,641,391 people (see Figure 1), where 3,955,679 cases were fatal with a fatality rate of $2.17 \%$ (from the virus outbreak until July 1, 2021). As the disease is not yet under control, it still significantly influences people's daily travel behaviors worldwide. Thus, it is urgent to investigate the changes in people's travel behaviors since the outbreak of the disease.

According to the observations on the influence of COVID-19 in Taiwan, the transport volume of the transit department shrank compared to the same period in the former year. As summarized in Table 1 and Figure 2, the substantial influence of COVID-19 in Taiwan began in February 2020, and there has been a significant decrease in the number of travel passengers, with the largest reduction in the number of air passengers. According to the statistics of the Ministry of Transportation and Communications, from February to May 2020, compared to the same period last year, there were 58.15 million railway passengers, which decreased by $19.76 \%, 25.68 \%, 36.01 \%$, and $21.55 \%$, respectively; 14.11 million high-speed railway passengers, which decreased by $26.86 \%, 37.52 \%, 48.10 \%$, and $32.97 \%$, respectively; 224.52 million mass rapid transit passengers, which decreased by $8.83 \%, 22.83 \%, 31.18 \%$, and $23.20 \%$, respectively; 323.1 million car passengers, which decreased by $10.36 \%, 20.03 \%, 25.95 \%$, and $20.97 \%$, respectively; 4.86 


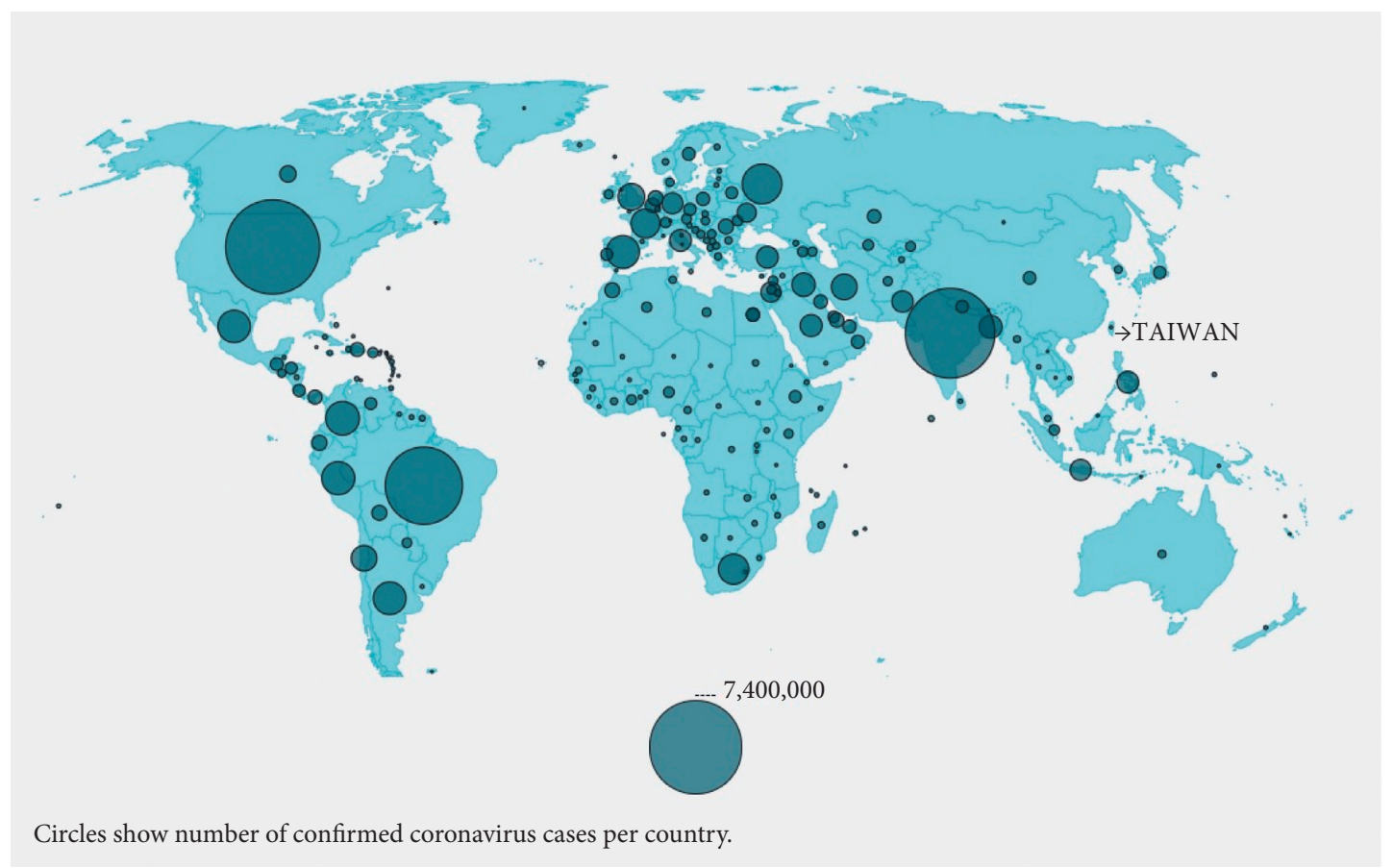

FIGURE 1: Accumulated COVID-19 confirmed cases globally (source: https://www.bbc.com/news/world-51235105).

TABle 1: Number of public transport passengers in Taiwan (10,000 people).

\begin{tabular}{|c|c|c|c|c|c|}
\hline Time & Railway & HSR & MRT & Bus & Air \\
\hline $2019 / 1$ & 1,953 & 533 & 7,600 & 10,542 & 431 \\
\hline $2019 / 2$ & 1,900 & 543 & 6,464 & 8,774 & 424 \\
\hline $2019 / 3$ & 2,017 & 565 & 7,557 & 10,754 & 457 \\
\hline 2019/4 & 2,007 & 568 & 7,168 & 10,407 & 487 \\
\hline $2019 / 5$ & 1,922 & 548 & 7,544 & 11,012 & 497 \\
\hline 2019/6 & 1,898 & 561 & 7,088 & 10,003 & 482 \\
\hline $2019 / 7$ & 1,951 & 562 & 7,499 & 10,232 & 502 \\
\hline 2019/8 & 1,912 & 556 & 7,340 & 9,939 & 504 \\
\hline $2019 / 9$ & 1,914 & 551 & 6,977 & 10,146 & 432 \\
\hline $2019 / 10$ & 2,054 & 580 & 7,732 & 10,933 & 465 \\
\hline $2019 / 11$ & 2,008 & 568 & 7,665 & 10,518 & 436 \\
\hline $2019 / 12$ & 2,080 & 608 & 8,308 & 11,433 & 422 \\
\hline $2020 / 1$ & 1,946 & 623 & 7,105 & 9,427 & 422 \\
\hline $2020 / 2$ & 1,525 & 397 & 5,888 & 7,750 & 198 \\
\hline $2020 / 3$ & 1,499 & 353 & 5,824 & 8,684 & 93 \\
\hline $2020 / 4$ & 1,284 & 295 & 4,929 & 7,576 & 43 \\
\hline $2020 / 5$ & 1,508 & 367 & 5,789 & 8,694 & 54 \\
\hline $2020 / 6$ & 1,664 & 443 & 6,071 & 8,830 & 90 \\
\hline $2020 / 7$ & 1,792 & 498 & 6,677 & 9,142 & 150 \\
\hline $2020 / 8$ & 1,807 & 549 & 6,664 & 8,982 & 163 \\
\hline $2020 / 9$ & 1,733 & 501 & 6,678 & 9,530 & 123 \\
\hline $2020 / 10$ & 1,900 & 572 & 6,813 & 9,594 & 129 \\
\hline $2020 / 11$ & 1,833 & 547 & 6,892 & 9,589 & 85 \\
\hline $2020 / 12$ & 1,862 & 579 & 7,521 & 10,059 & 74 \\
\hline $2021 / 1$ & 1,638 & 466 & 6,608 & 8,852 & 69 \\
\hline $2021 / 2$ & 1,531 & 446 & 5,623 & 7,224 & 76 \\
\hline $2021 / 3$ & 1,799 & 516 & 7,014 & 9,504 & 78 \\
\hline $2021 / 4$ & 1,805 & 551 & 6,691 & 9,048 & 113 \\
\hline
\end{tabular}

Source: Department of Statistics, Ministry of Transportation and Communications (2021). 


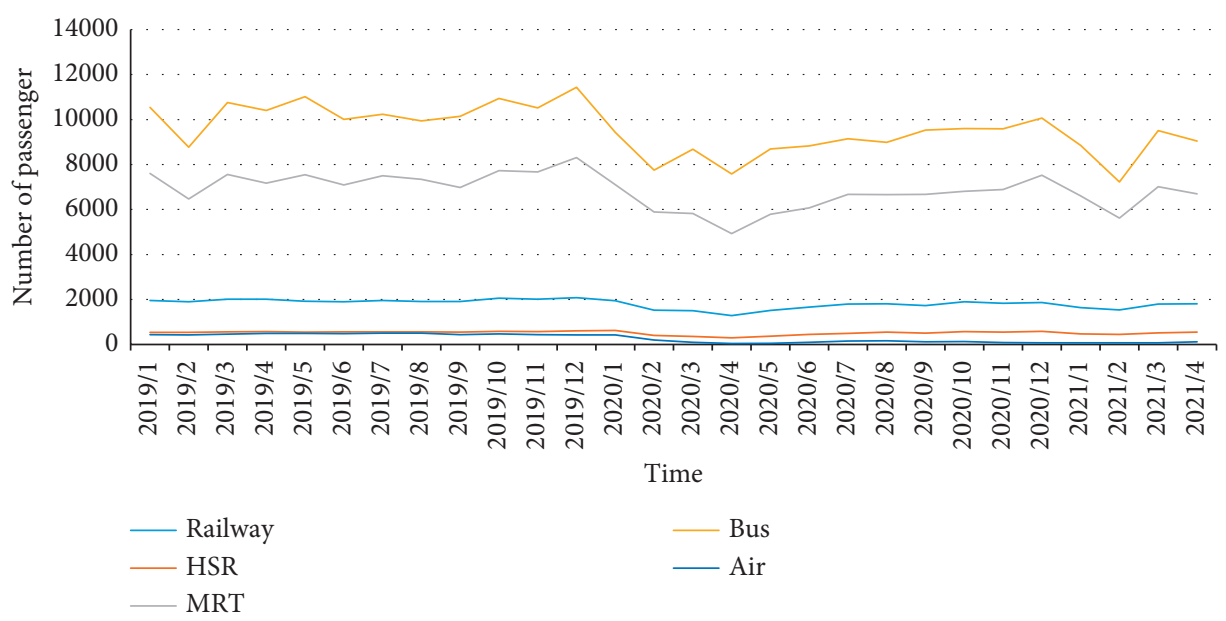

FIGURE 2: Number of transit passengers in Taiwan (source: https://www.cdc.gov.tw/Category/NewsPage/EmXemht4IT-IRAPrAnyG9A).

million air passengers, which decreased by $48.75 \%, 82.52 \%$, 93.25\%, and $91.40 \%$, respectively.

Therefore, with the increasing influence of the COVID-19 pandemic, the use of public transportation in Taiwan has decreased significantly. Such decrease mainly results from Taiwanese people using other modes of transport or reducing their travels to avoid prolonged exposure to the COVID-19 virus in public places. The biggest drop in air passengers was caused by canceled flights or the strict control of passenger entry according to airport control measures. Chiu et al. [1] stated that such a phenomenon would significantly change travel behaviors and that the sudden changes in travel behaviors caused by such infectious diseases are worth further understanding so that appropriate emergency measures could be put forward to improve the traffic problems arising from travelers changing their means of transport.

As summarized in Table 2 and Figure 3, the substantial influence of COVID-19 in Taiwan began in February 2020. The data were significantly reduced according to the statistics of million kilometers traveled by vehicles on freeways although by a smaller margin than transit data. From February to May 2020, the total number of million kilometers traveled was 10743.2, which decreased by $6.36 \%, 6.11 \%, 7.49 \%$, and $-1.85 \%$, respectively, compared to the same period last year, indicating that Taiwanese people tended to reduce their travels with the increasing influence of the COVID-19 pandemic to avoid being infected. By May 2020, due to the gradual ease of the pandemic in Taiwan, the million kilometers traveled of vehicles on freeways increased by $50.6(1.85 \%)$ compared to the same period last year. However, Figure 2 shows that the transit usage in May 2020 had not returned to the previous year's level, indicating that transit passengers may have switched to private vehicles. This shift may suggest a niche for promoting the use of EVs (electrical vehicles). It is noteworthy that, as mentioned by Kaya et al. [2], the issues of range and charging station infrastructure must be solved so that the widespread use of EVs can be facilitated. It is critical to implement optimal planning and design of the infrastructure, especially the areas equipped with charging stations, in order to increase the number of electric vehicles in circulation [3].
TABLE 2: Statistics of one million kilometers traveled of vehicles on freeways.

\begin{tabular}{|c|c|c|c|}
\hline $\begin{array}{l}\text { Date/directions of national } \\
\text { freeways }\end{array}$ & Southbound & Northbound & Total \\
\hline 2019/1 & $1,417.1$ & $1,422.3$ & $2,839.4$ \\
\hline $2019 / 2$ & $1,415.4$ & $1,379.7$ & $2,795.0$ \\
\hline $2019 / 3$ & $1,444.2$ & $1,451.5$ & $2,895.7$ \\
\hline $2019 / 4$ & $1,422.1$ & $1,415.7$ & $2,837.8$ \\
\hline $2019 / 5$ & $1,370.5$ & $1,360.8$ & $2,731.3$ \\
\hline $2019 / 6$ & $1,391.6$ & $1,381.5$ & $2,773.1$ \\
\hline $2019 / 7$ & $1,427.8$ & $1,420.8$ & $2,848.6$ \\
\hline $2019 / 8$ & $1,386.5$ & $1,373.2$ & $2,759.7$ \\
\hline $2019 / 9$ & $1,373.8$ & $1,370.9$ & $2,744.7$ \\
\hline $2019 / 10$ & $1,424.2$ & $1,418.3$ & $2,842.5$ \\
\hline 2019/11 & $1,383.1$ & $1,369.0$ & $2,752.1$ \\
\hline $2019 / 12$ & $1,419.0$ & $1,414.2$ & $2,833.2$ \\
\hline $2020 / 1$ & $1,514.7$ & $1,490.1$ & $3,004.8$ \\
\hline $2020 / 2$ & $1,316.2$ & 1,301.1 & $2,617.2$ \\
\hline $2020 / 3$ & $1,358.1$ & $1,360.7$ & $2,718.9$ \\
\hline $2020 / 4$ & $1,317.3$ & $1,308.0$ & $2,625.2$ \\
\hline $2020 / 5$ & $1,393.6$ & $1,388.3$ & $2,781.9$ \\
\hline $2020 / 6$ & $1,434.1$ & $1,430.8$ & $2,864.9$ \\
\hline $2020 / 7$ & $1,480.0$ & $1,466.2$ & $2,946.2$ \\
\hline $2020 / 8$ & $1,504.2$ & $1,500.3$ & $3,004.5$ \\
\hline $2020 / 9$ & $1,410.5$ & $1,393.3$ & $2,803.8$ \\
\hline $2020 / 10$ & $1,502.2$ & $1,498.4$ & $3,000.6$ \\
\hline $2020 / 11$ & $1,414.7$ & $1,411.9$ & $2,826.6$ \\
\hline $2020 / 12$ & $1,478.0$ & $1,458.3$ & $2,936.3$ \\
\hline $2021 / 1$ & $1,444.0$ & $1,447.0$ & $2,891.0$ \\
\hline $2021 / 2$ & $1,423.2$ & $1,402.0$ & $2,825.2$ \\
\hline $2021 / 3$ & $1,443.8$ & $1,447.6$ & $2,891.4$ \\
\hline $2021 / 4$ & $1,468.3$ & $1,453.9$ & $2,922.2$ \\
\hline
\end{tabular}

Source: Freeway Bureau (2020) MOTC (https://www.freeway.gov.tw/ Publish.aspx?cnid=1656).

Since the COVID-19 outbreak, there has been an increase in confirmed cases around the world, which has changed along with policy changes (see Table 3 ). This study summarized the statistics of the Taiwan Centers for Disease Control. As shown in Table 4 and Figure 4, the number of the confirmed COVID19 cases in Taiwan indicates that the disease was the most 


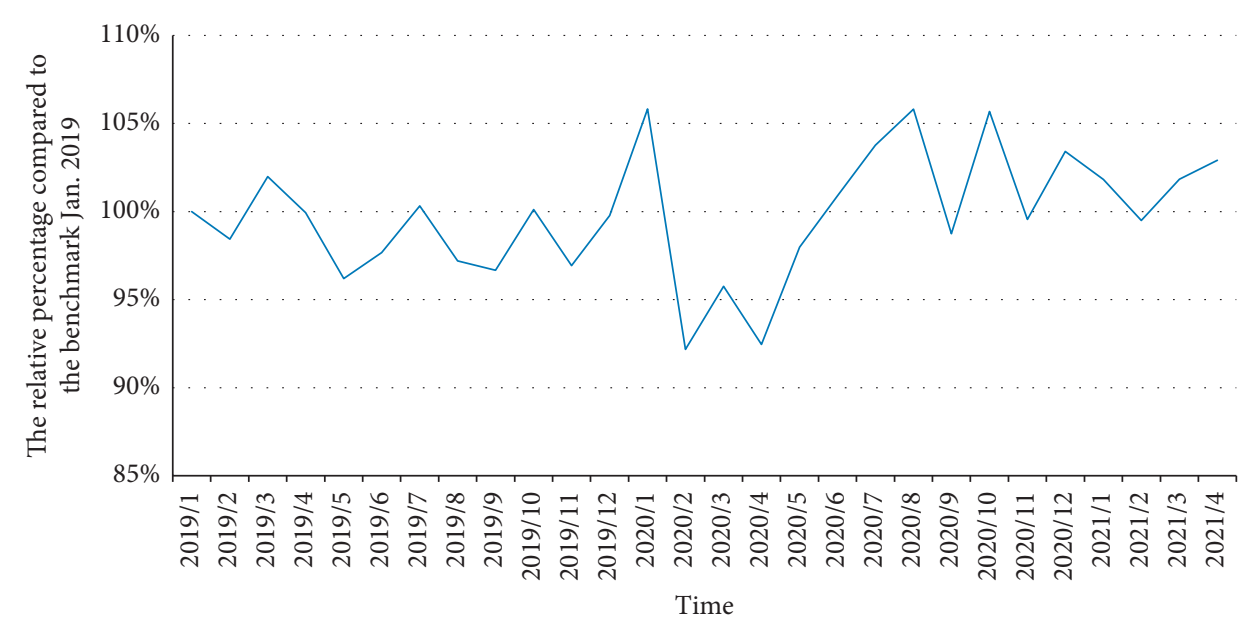

FIGURE 3: Statistics of one million kilometers of vehicle traveled on freeways (with January 2019 as the benchmark) (source: Freeway Bureau (2020) MOTC (https://www.freeway.gov.tw/Publish.aspx?cnid=1656)).

TABle 3: Key timeline for COVID-19 in Taiwan.

\begin{tabular}{|c|c|c|}
\hline Date & Events & Descriptions \\
\hline $\begin{array}{l}\text { January } 7, \\
2020\end{array}$ & Outbreak in Wuhan & $\begin{array}{l}\text { As reported by the Central News Agency [4], the Taiwan } \\
\text { Centers for Disease Control rated its travel advice for Wuhan } \\
\text { as level } 1\end{array}$ \\
\hline $\begin{array}{l}\text { January 21, } \\
2020\end{array}$ & First confirmed case in Taiwan & $\begin{array}{c}\text { After Taiwan's first case was confirmed, the Taiwan Centers } \\
\text { for Disease Control [4] raised its travel advice for Wuhan, } \\
\text { Hubei, China, to level } 3 \text { during the pandemic. }\end{array}$ \\
\hline $\begin{array}{l}\text { February } 6, \\
2020\end{array}$ & Real-name registration system for mask purchases & $\begin{array}{l}\text { According to the Taiwan Centers for Disease Control [4], the } \\
\text { world panicked to buy masks. In order to prohibit people } \\
\text { from rushing to buy and hoard masks, the real-name } \\
\text { registration system was implemented, which made masks } \\
\text { available to those in need and ensured fair and transparent } \\
\text { use of resources. }\end{array}$ \\
\hline $\begin{array}{l}\text { February 18, } \\
2020\end{array}$ & Diamond Princess was listed as an infected area & $\begin{array}{l}\text { In a press release, the Taiwan Centers for Disease Control [4] } \\
\text { noted that the Central Epidemic Command Center } \\
\text { announced that cruise ships had been listed as infected areas. } \\
\text { Any Taiwanese passengers (including tourists and staff) on } \\
\text { board who wanted to return home must take a charter flight } \\
\text { in accordance with the arrangement of the Command Center } \\
\text { and observe the quarantine measures. }\end{array}$ \\
\hline $\begin{array}{l}\text { February 27, } \\
2020\end{array}$ & Travel advice for Italy was raised to warning level 3 & $\begin{array}{l}\text { In a press release, the Taiwan Centers for Disease Control [4] } \\
\text { noted that the Central Epidemic Command Center said that } \\
\text { the number of COVID-19 cases and deaths in Italy had } \\
\text { increased rapidly. Due to the increased risk of people } \\
\text { traveling to Italy, the Command Center announced that the } \\
\text { travel advisory for Italy would be raised to level 3: "Warning, } \\
\text { reminding people not to travel unless necessary". }\end{array}$ \\
\hline $\begin{array}{l}\text { March 17, } \\
2020\end{array}$ & Global travel advice was raised to warning level 1 or above & $\begin{array}{c}\text { In a press release, the Taiwan Centers for Disease Control [4] } \\
\text { noted that the Central Epidemic Command Center said that } \\
\text { the travel advice for } 13 \text { countries in Eastern Europe, } 15 \\
\text { countries and } 1 \text { region in the Middle East, } 5 \text { countries in } \\
\text { North Africa, and } 9 \text { countries in Central Asia would be raised } \\
\text { to level } 3 \text { from 0:00 on } 17 \text { March: "Warning, reminding } \\
\text { people not to travel unless necessary." }\end{array}$ \\
\hline
\end{tabular}


TABLE 3: Continued.

\begin{tabular}{lll}
\hline Date & Events & Descriptions
\end{tabular}

In a press release, the Taiwan Centers for Disease Control [4] noted that the first stage is gentle persuasion. It is suggested that people avoid attending exhibitions, sports competitions, concerts, and other social activities with close contact, as well

as entering entertainment places irrelevant to their

April 1, $2020 \quad$ First-stage notes for maintaining social distance livelihood. Moreover, it is suggested that people keep a distance of $1.5 \mathrm{~m}$ indoors and $1 \mathrm{~m}$ outdoors. If masks are worn correctly, social distancing can be exempted. However, masks shall be worn in crowded and closed places. If a place has a high probability of close contact and cannot effectively maintain a social distance of $1.5 \mathrm{~m}$, the owner shall stop business.

In a press release, the Taiwan Centers for Disease Control [4] noted that, with the ease of the pandemic in Taiwan, it was hoped that people would feel assured to participate in various outdoor activities to enable people to return to normal life gradually. These activities include enjoying outdoor concerts, art performances, and sports events, or

April 30, $2020 \quad$ New life movement during pandemic prevention participating in outings, sports, tourism, and other activities beneficial to physical and mental health, under the condition of observing personal prevention measures (washing hands frequently, wearing masks when unable to maintain social distance, and when traveling by transit). In addition, when going out to eat in restaurants or at street vendors, people should choose those with proper dining distance, clapboard separators, and set meals.

The Central Epidemic Command Center announced that there would be no restrictions on the flow of people in the venues of art, food and beverage, and leisure activities. The

Taiwan's government has implemented relaxation of the pandemic control policy and started to lift the lockdown measures in a large-scale manner

July 15,2020

December 21, 2020

January 12, The outbreak of the second wave of local infection cases in 2021 Taiwan

February 20, The Ministry of Health and Welfare in Taiwan authorized 2021

March 3, 2021 the use of the $\mathrm{AZ}$ vaccine

The first batch of $\mathrm{AZ}$ vaccines in Taiwan began to be distributed

April 20, 2021
A large-scale outbreak of local infection cases
Taiwan Railways and Taiwan High-Speed Rail will also lift the ban on eating and drinking and sell free seats. However, passengers of the MRT still need to wear masks due to the heavy passenger capacity.

In response to the economic recession caused by the COVID-19 pandemic, the Executive Yuan issued the Triple Stimulus Voucher program for economic revitalization. Starting from July 15, each person will receive a Triple Stimulus Voucher worth NT $\$ 3,000$.

A confirmed case, a New Zealand EVA pilot, infected 2 colleagues and 1 friend, breaking the record of 0 local cases in Taiwan for 81 days.

According to the Ministry of Health and Welfare, the

Taoyuan Hospital experienced a cluster outbreak of infections. A lockdown was implemented for some areas in the hospital for containment. There were 21 confirmed cases. TFDA, MOHW announced the approval to authorize the use of the AZ vaccine and approved vaccines produced by manufacturers in Germany, South Korea, and Italy.

The first batch of $\mathrm{AZ}$ vaccines began to be distributed in 57 hospitals across Taiwan

The scope of infection continued to expand, affecting various areas, including Wanhua District, Taipei City, Luzhou

District, New Taipei City, Yilan County, and other areas. Since then, Taiwan entered a period of large-scale infection outbreaks, where the source of infection is unknown. 
TABLE 3: Continued.

\begin{tabular}{|c|c|c|}
\hline Date & Events & Descriptions \\
\hline May 15, 2021 & $\begin{array}{c}\text { Taipei City and New Taipei City were upgraded to level } 3 \\
\text { alert }\end{array}$ & $\begin{array}{c}\text { The Executive Yuan and the Central Epidemic Command } \\
\text { Center announced that Taipei City and New Taipei City areas } \\
\text { have entered level } 3 \text { alert. The three main measures are (1) } \\
\text { wear masks all the time when going out; (2) no gatherings of } \\
\text { more than } 5 \text { people indoors and more than } 10 \text { people } \\
\text { outdoors; ( } 3 \text { ) business and public areas, except for those for } \\
\text { life support, order maintenance, essential services, medical, } \\
\text { and official needs, should be closed. }\end{array}$ \\
\hline May 19, 2021 & All areas in Taiwan upgraded to level 3 alert & $\begin{array}{l}\text { From now until May } 28 \text {, the national pandemic alert has } \\
\text { been raised to level } 3 \text {. }\end{array}$ \\
\hline May 28, 2021 & $\begin{array}{c}\text { Level } 3 \text { alert period extended for the second time across } \\
\text { Taiwan }\end{array}$ & $\begin{array}{l}\text { With the undiscovered hidden cases in the communities, the } \\
\text { alert was extended to June } 14 .\end{array}$ \\
\hline June 07, 2021 & $\begin{array}{l}\text { Level } 3 \text { alert period extended for the third time across } \\
\text { Taiwan }\end{array}$ & $\begin{array}{c}\text { Level } 3 \text { alert was extended for the third time until } 28 \text { June. As } \\
\text { of June 07, 2021, the cumulative number of confirmed cases } \\
\text { in Taiwan reached } 11,491 \text {. }\end{array}$ \\
\hline June 14, 2021 & $\begin{array}{l}\text { The outbreak of the first Delta variant infection case in } \\
\text { Taiwan }\end{array}$ & $\begin{array}{c}\text { After home isolation, citizens returning to Taiwan from Peru } \\
\text { were diagnosed on June } 14 \text {. After genetic sequencing, the } \\
\text { virus strain was confirmed to be the Delta variant virus } \\
\text { strain. }\end{array}$ \\
\hline June 23, 2021 & $\begin{array}{l}\text { Level } 3 \text { alert period extended for the fourth time across } \\
\text { Taiwan }\end{array}$ & $\begin{array}{c}\text { Level } 3 \text { alert was extended for the fourth time to } 12 \text { July. As of } \\
\text { June } 23,2021 \text {, the cumulative number of confirmed cases in } \\
\text { Taiwan reached } 14,260 \text {. }\end{array}$ \\
\hline
\end{tabular}

TABle 4: Statistics of confirmed COVID-19 cases in Taiwan.

\begin{tabular}{|c|c|c|c|c|}
\hline Month\cases & Imported cases & Indigenous cases & Total cases & Imported cases $(\%)$ \\
\hline $2020 / 1$ & 8 & 2 & 10 & 80.00 \\
\hline $2020 / 2$ & 10 & 19 & 29 & 34.48 \\
\hline $2020 / 3$ & 258 & 25 & 283 & 91.17 \\
\hline $2020 / 4$ & 98 & 9 & 107 & 91.59 \\
\hline $2020 / 5$ & 13 & 0 & 13 & 100.00 \\
\hline $2020 / 6$ & 5 & 0 & 5 & 100.00 \\
\hline $2020 / 7$ & 20 & 0 & 20 & 100.00 \\
\hline $2020 / 8$ & 18 & 1 & 19 & 94.74 \\
\hline $2020 / 9$ & 26 & 0 & 26 & 100.00 \\
\hline $2020 / 10$ & 38 & 0 & 38 & 100.00 \\
\hline $2020 / 11$ & 117 & 0 & 117 & 100.00 \\
\hline $2020 / 12$ & 119 & 0 & 119 & 100.00 \\
\hline $2021 / 1$ & 84 & 17 & 101 & 83.17 \\
\hline $2021 / 2$ & 40 & 2 & 42 & 95.24 \\
\hline $2021 / 3$ & 75 & 0 & 75 & 100.00 \\
\hline $2021 / 4$ & 14 & 21 & 35 & 40.00 \\
\hline $2021 / 5$ & 140 & 7,230 & 7,370 & 1.90 \\
\hline $2021 / 6$ & 31 & 5,198 & 5,229 & 0.59 \\
\hline $2021 / 7$ & 12 & 196 & 208 & 5.77 \\
\hline
\end{tabular}

Source: Taiwan Centers for Disease Control (2020/01-2021/07).

severe in March 2020, and the data of imported cases and indigenous cases indicate that imported cases accounted for the majority. In February 2020, imported cases accounted for $34.48 \%$ of the total cases, indicating the most severe infection in communities. In other months, imported cases accounted for more than $80 \%$. In early April 2020, after the implementation of the "first-stage notes for maintaining social distance" (see Table 3 for other measures), there was a significant decrease in indigenous cases. After May 2020, the number of indigenous cases dropped to zero.

This study carried out questionnaire design and data collection in Taiwan, which are revised based on the computer questionnaire of Becker and Hensher [5]. The analysis results can serve as a reference for Taiwan to cope with similar large-scale pandemics in the future and compare the changes in travel behaviors in different regions. This study investigated and analyzed the changes in current daily travel behaviors from 24 April 2020 to 02 May 2020 compared to prepandemic travel behaviors. In order to determine whether travel behaviors (changes in travel frequency) have remained the same or decreased, this study adopted logistic regression models to capture the important factors influencing travel reduction. Moreover, this study used the ordered logit model-which can distinguish the degree of 


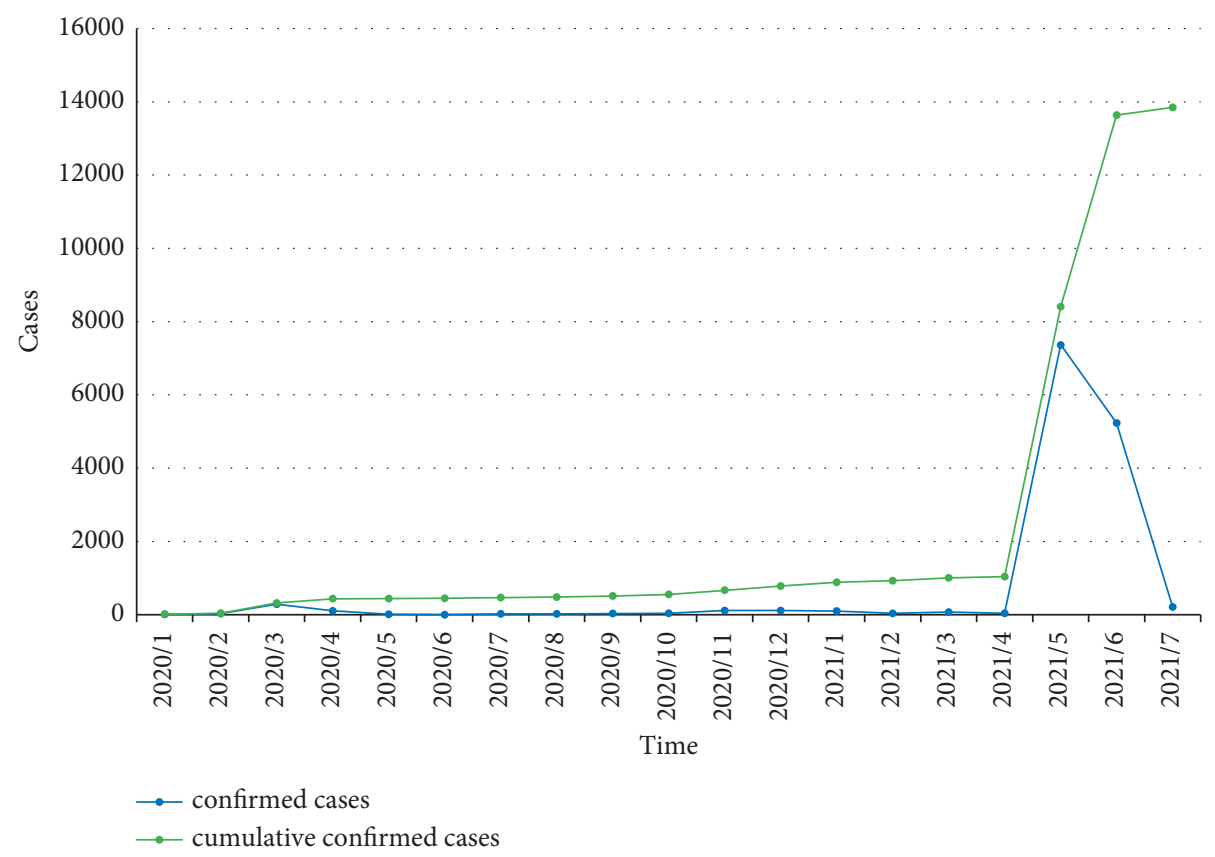

Figure 4: Statistics of confirmed COVID-19 cases in Taiwan (source: Taiwan Centers for Disease Control (2020/01-2021/07)).

travel reduction-to discuss the important factors influencing the different degrees of travel reductions.

The contributions of this study are threefold. First, this study stands as the first research to investigate the influence of COVID-19 on the changes in travelers' behaviors in Taiwan. Second, an econometric model suitable to explain the changes in travelers' behaviors in Taiwan due to the pandemic is established. Third, important attributes that contributed to model estimations are found and provided some insightful results, which can be valuable to pandemic management in the future.

\section{Literature Review}

One of the focuses of this study is to investigate the changes in travel behaviors in people's daily life under severe virus infection. Econometric models are used for analysis in order to conduct an in-depth investigation of important influencing factors. This section is based on a literature review on pandemics. In particular, Section 2.1 includes a review of the changes in travel behaviors, while Section 2.2 includes a review of the econometric models.

2.1. Changes in Travel Behaviors. Beck and Hensher [5] collected data through online questionnaires and pointed out a significant difference in travel behaviors before and after the COVID-19 outbreak. However, there was no significant difference between the present situations and possible future changes, implying a gradual balance of travel behaviors. In addition, pandemic diseases disrupt work and travel, which influence overall social well-being, as demonstrated in the studies of Stanley et al. [6-8]; that is, using small passenger cars as a means of transport has no major influence on daily travel behaviors or social wellbeing [9].

According to Graham et al. [10], the influence of COVID-19 has been quite severe. They found that more than $60 \%$ of elderly British citizens (over 65) intended to have a few air travels the next year. These samples considered that they would have the lowest risk of infection upon arrival at or departure from airports during the entire journey, highlighting that airlines and airport services should provide self-check-in desks or other service interfaces for the elderly to reduce the risk of being infected as a way to cope with pandemic diseases.

De Vos [11] observed that necessary control measures are currently taken to prevent the spread of COVID-19, and travels and events in many countries have been restricted. Social distance control means reducing interpersonal interactions to slow the spread of the virus. During the spread of the pandemic, people have traveled less, avoided taking transits, and preferred to use private vehicles. While reduced demand for travel may lead to social isolation and a negative influence on subjective well-being, walking and riding bicycles may have an important influence on maintaining happiness; hence, short travels and leisure travels may increase.

Graham et al. [10] pointed out that elderly passengers tend to use private vehicles to and from airports. As traveling by transit is considered risky, the COVID-19 pandemic may intensify elderly passengers' preference for private vehicles, and getting to and from airports is less risky than being in terminals or on planes. It seems that environmental hygiene, rather than flexible air tickets, is the most important factor currently influencing elderly passengers' travel behaviors. While new technologies can reduce the frequency of interaction with others, they are considered the least important factor for elderly passengers. 
Zheng et al. [12] found that the frequencies of public transport departures in Wuhan City had a significant positive influence on the daily increase of COVID-19 cases in other cities in China. The distance between Wuhan City and another city was inversely proportional to the number of COVID-19 cases in that city. According to their studies, the correlation and distances between infectious disease centers and the destinations are important determinants of virus transmission. Thus, in order to control the COVID-19 pandemic, strong preventive measures should be taken in cities close to public transport, and there should be frequent interactions with infectious disease centers.

$\mathrm{Wu}$ et al. [13] pointed out that further international spread and local spread of COVID-19 are inevitable without immediate and extensive public health restrictions. According to current trends, COVID-19 may become a pandemic without mitigation measures. Strict measures must be taken immediately in affected areas to restrict population mobility, such as canceling mass meetings, closing schools, and making work-from-home arrangements. While all restrictions shall be made according to local conditions, it must be noted that there is no standard measure suitable for all situations.

Musselwhite et al. [14] pointed out that, due to the COVID-19 pandemic, many countries were forced to take control measures that would significantly influence travel behaviors. For instance, video conferencing would become normal for office workers. As traffic conditions are varied from region to region and among populations, the lockdown has disproportionately influenced traffic. Moreover, migrant workers might not be able to make ends meet and may lose their jobs. Thus, it would be difficult to live without the government's financial support and assistance.

Lau et al. [15] pointed out that air travel was the main cause of the spread of COVID-19 and that the virus was also spread by other transportation means in Taiwan. The number of international cases is directly related to the number of routes and passengers, and Taiwan's flights and other transportation means might also influence the number of cases.

Regarding the changes in travel behaviors before, during, and after SARS, Chiu et al. [1] pointed out that the transportation volumes significantly decreased after the outbreak, indicating that people reduced their travels or only traveled by private vehicles to avoid being infected. The proportion of people using private vehicles increased during that pandemic. After it eased, the travel habits of some people did not return to their previous situations. Thus, travel frequency might increase due to the economic effects of incentives offered by operators.

Some research focused on the effects of a pandemic on the collapse of public transport use to better define the development of mobility in the pandemic phase. For example, Dong et al. [16] studied passengers' psychological responses to the pandemic over time in terms of emotional arousal and mental construal as public transport begins to resume its operations with the pandemic almost entirely contained. Campisi et al. [17] revealed that public transport demand collapsed, especially during the lockdown period
(March-May 2020) in Sicily, Italy, and adverse effects were reported even in the subsequent periods. In fact, the social distancing restrictions have highlighted numerous problems with public transport systems worldwide. Vickerman [18] explored the challenge posed to current public transport services and argued that a return to the status quo is unlikely as public transport adjusts to a new normal of more home working and fear of crowded spaces.

Chang et al. [19] mentioned that during the COVID-19 pandemic, the preferred means of transportation on working days changed from public transportation to private transportation. In particular, the use of MRT and shared bicycles dropped by an average of $8 \%$ to $18 \%$, while the use of cars and locomotives increased by $11 \%$ to $21 \%$ during the working day. Cusack [20] indicated that those who take public transportation to work before the epidemic are likely to change their commuting modes after the outbreak. Interviewees described the main reasons for changing commuting modes were due to the concerns about public transportation safety and environmental cleanliness. Fumagalli et al. [21] investigated the effects of the COVID-19 epidemic in Brazil and found out Curitiba's public transport system could reach 1.36 million passengers per day before the outbreak. When the restrictions and control measures were implemented in mid-March 2020, the daily passenger volume dropped to $80 \%$, and many passenger routes have been canceled, leaving only 200,000 passengers per day. Padmanabhan et al. [22] pointed out that during the COVID-19 pandemic, public transportation and air transportation are the most affected modes of transportation because it is extremely difficult to maintain social distance in these modes of transportation. According to related policies, the number of trips using cars has also decreased significantly.

Shakibaei et al. [23] investigated the effects of pandemic on travel behavior in Istanbul, Turkey. This study conducted a longitudinal panel survey in three phases during the outbreak of COVID-19. The results showed that the transition in travel behavior was fairly extreme, especially for commuting trips and social/recreational/leisure trips. Eisenmann et al. [24] analyzed overall and individual changes in travel modes and attitude towards travel modes. The results showed that the private car was more important than public transport to travelers during the lockdown period. On the other hand, Awad-Núñez et al. [25] obtained the opposite result which indicated most respondents would accept restrictions on car use and reduction of public space devoted to the car after the COVID-19. Scorrano and Danielis [26] detected a highly substitute effect between the bus and the bike, while much less influence was found between the car and the motorcycle. The results confirmed that the COVID-19 has a negative impact on bus, and bus riders tend to switch to private modes.

2.2. Logistic Regression and Ordered Logit Models. Elldér [27] used logistic regression to establish a model to determine whether remote work would reduce travel frequency and found that people who work remotely full-time were 
significantly less likely to travel than those who work remotely part-time or work on-site. The study also showed that men, the elderly, low-income people, and people living far from downtown are more likely to stay indoors. Finally, a model was established for the possibility of travel during peak hours, which confirmed that people who work full-time remotely are less likely to travel during peak hours and that those who work remotely part-time travel more frequently during peak hours than those who work on-site. Furthermore, the marginal utility was twice as large as those who work all day remotely. However, women, the elderly, low-income people, people owning no vehicle, and people lacking higher education are less likely to travel during peak hours.

Beck and Hensher [5] pointed out that the percentage of total vehicle miles traveled decreased by $35 \%$ in Australia under the influence of COVID-19. For those households that reduced their car usage, the average reduction was $60 \%$. While both low-income and high-income households significantly reduced their car use, high-income households account for the largest reduction. In terms of the number of households increasing their car usage, the average increase was $44 \%$. To explain the changes in car use, the authors cited ordered logit models and conducted ranking based on the situation that respondents might reduce, maintain, or increase their car usage. Various socioeconomic and demographic variables were tested and found to be unimportant. Thus, they were excluded from the models. All groups of people reduced car use, and the models showed that the real reasons for working from home are employee abilities and employers' support. Therefore, the reduction of car use is unrelated to occupation, age, gender, or income. According to the aforementioned study, the two variables-employers' directions to work from home and cars used as the main means to commute before the outbreak-had a significant influence on the changes in car use. Moreover, according to the study results, the respondents who mainly commuted by transit before the outbreak used their cars frequently-perhaps, because they were less confident about the sanitary conditions of public transport.

\section{Methodology}

This study mainly investigated the changes in people's daily travel behaviors after the COVID-19 outbreak and estimated coefficients by econometric models to determine the significant factors influencing daily travel behaviors and the degree of their influence as the main basis for setting future transport policies after the outbreak of similar situations. The application models of the statistical methods are described as follows.

3.1. Logistic Regression Model. We assume the dependent variable $Y$ is a binary variable, and $p$ is the probability of its success ( $p$ is between 0 and 1). If $p$ is close to 0 , it indicates that $Y$ has a small probability of success. If $p$ is close to 1 , it indicates that $Y$ has a large probability of success and is influenced by the dependent variable $x$. The relationship between $p$ and $x$ can be expressed as follows:

$$
\begin{gathered}
p(Y=1 \mid X=x)=\frac{e^{f(x)}}{1+e^{f(x)}}=\frac{e^{x^{\prime} \beta}}{1+e^{x^{\prime} \beta}} \\
1-p(Y=1 \mid X=x)=\frac{1}{1+e^{f(x)}}=\frac{1}{1+e^{x^{\prime} \beta}}
\end{gathered}
$$

where the odds ratio is defined as the ratio between the probability of success and the probability of failure of an event. It can be expressed as follows:

$$
\frac{p}{1-p}=e^{f(x)}
$$

The logistic regression can be expressed as follows:

$$
\ln \frac{p}{1-p}=f(x)=\beta_{0}+\beta_{1} x_{1}+\beta_{2} x_{2}+\cdots+\beta_{m} x_{m}
$$

where $m$ represents the number of independent variables. The logistic regression is estimated by the maximum likelihood estimation (MLE). Its likelihood function is expressed as follows:

$$
L(\beta)=\prod_{i=1}^{n} p_{i}^{y_{i}}\left(1-p_{i}\right)^{1-y_{i}}
$$

3.2. Ordered Logit Model. To further discuss the influence of the COVID-19 outbreak on the current rate of travel reduction, the number of weekly reductions is divided into 3 levels, which are considered ordinal variables. In the models, we assume the threshold level of travel reduction is $\mu_{k}, k=0,1,2$. If $k$ is 0 , it indicates the minimum threshold; that is, there is no travel reduction within the level, followed by 1 to 7 reductions per week (1 reduction per day on average) and more than 8 reductions per week (about more than 2 reductions per day on average).

When the error term in the model, as shown in (5), is assumed to be logistically distributed, the ordered logit model can be deduced. Its model form is as follows:

$$
Y^{*}=x^{\prime} \beta+\varepsilon
$$

where $Y^{*}$ is the random variable that cannot be observed and is the dependent variable, $x$ is the explanatory variable, $\beta$ is the parameter to be estimated, and $\varepsilon$ is the error term. In this study, $Y^{*}$ is the degree of travel reduction, where a large $Y^{*}$ indicates a high degree of travel reduction. As $Y^{*}$ is the variable that cannot be observed in the model, the level thresholds assumed to reduce in the model are defined as follows:

$$
Y=k, \quad \text { if } \mu_{k-1}<Y^{*} \leq \mu_{k}, k=0,1,2 .
$$

$Y$ can be expressed as follows:

$$
Y= \begin{cases}0, & \text { if } \mu_{-1}<Y^{*} \leq \mu_{0}, \\ 1, & \text { if } \mu_{0}<Y^{*} \leq \mu_{1}, \\ 2, & \text { if } \mu_{1} Y^{*} \leq \mu_{2},\end{cases}
$$

where $\mu_{-1}=-\infty, \mu_{2}=\infty$. From (6) and (7): 


$$
\begin{array}{ll}
Y=0, & \text { if } \varepsilon \leq \mu_{0}-x^{\prime} \beta, \\
Y=1, & \text { if } \mu_{0}-x^{\prime} \beta<\varepsilon \leq \mu_{1}-x^{\prime} \beta, \\
Y=2, & \text { if } \varepsilon>\mu_{1}-x^{\prime} \beta .
\end{array}
$$

The probability of the number of travels on each level can be further expressed as follows:

$$
\begin{aligned}
& p(Y=0)=F\left(\mu_{0}-x^{\prime} \beta\right), \\
& p(Y=1)=\left\{F\left(\mu_{1}-x^{\prime} \beta\right)-F\left(\mu_{0}-x^{\prime} \beta\right)\right\}, \\
& p(Y=2)=\left\{1-F\left(\mu_{1}-x^{\prime} \beta\right)\right\} .
\end{aligned}
$$

$F$ is the logit cumulative distribution function:

$$
F(z)=\frac{e^{z}}{1+e^{z}},
$$

where $\beta$ is the regression coefficient of $X$, and according to the above equation, its values are the same on all satisfaction levels. In other words, the slope effects of all independent variables are the same, which is the parallel lines assumption of the ordered logit model.

3.3. Questionnaire Design. This study aimed to investigate the changes in mode choice and the number of travels before and during COVID-19. The customized online questionnaire of this study was written through SurveyMonkey, which consists of 3 parts: (1) socioeconomic characteristics, (2) travel characteristics, and (3) mode choice, which are described below.

3.3.1. Socioeconomic Characteristics. Socioeconomic characteristics include as follows: (1) gender; (2) age: 18 to 85, with 14 levels; (3) occupation: white collar class (management or administrative staff), white collar class (professionals), white collar class (soldiers, civil servants, and teachers), blue collar class (factory operators and workers), individual dealers (such as company owners), housekeepers, students, and others; (4) place of residence: six municipalities (Taipei City, New Taipei City, Taoyuan City, Taichung City, Tainan City, and Kaohsiung City, see Figure 5), and others; (6) monthly household income: less than NTD (1 $\mathrm{USD}=30$ NTD) 50,000, NTD 50,001-75,000, NTD 75, 001-100,000, NTD 100,001-125,000, NTD 125,001-150,000, NTD 150,001-175,000, NTD 175,001-200,000, NTD 200, 001-225,000, NTD 225,001-250,000, NTD 250,001-275,000, NTD 275,001-300,000, more than NTD 300,001; (7) number of cars owned; (8) number of motorcycles owned; (9) number of family members or friends living at the place of residence (including oneself); (10) number of family members or friends under 18 living at the place of residence.

3.3.2. Travel Characteristics. Transportation is an extended demand, and travel purposes are related to various socioeconomic activities. In this study, travel purposes are classified into 8 categories: commute, business, going to school, parenting, purchasing consumer goods, shopping, personal affairs, and social contact/recreation. Respondents

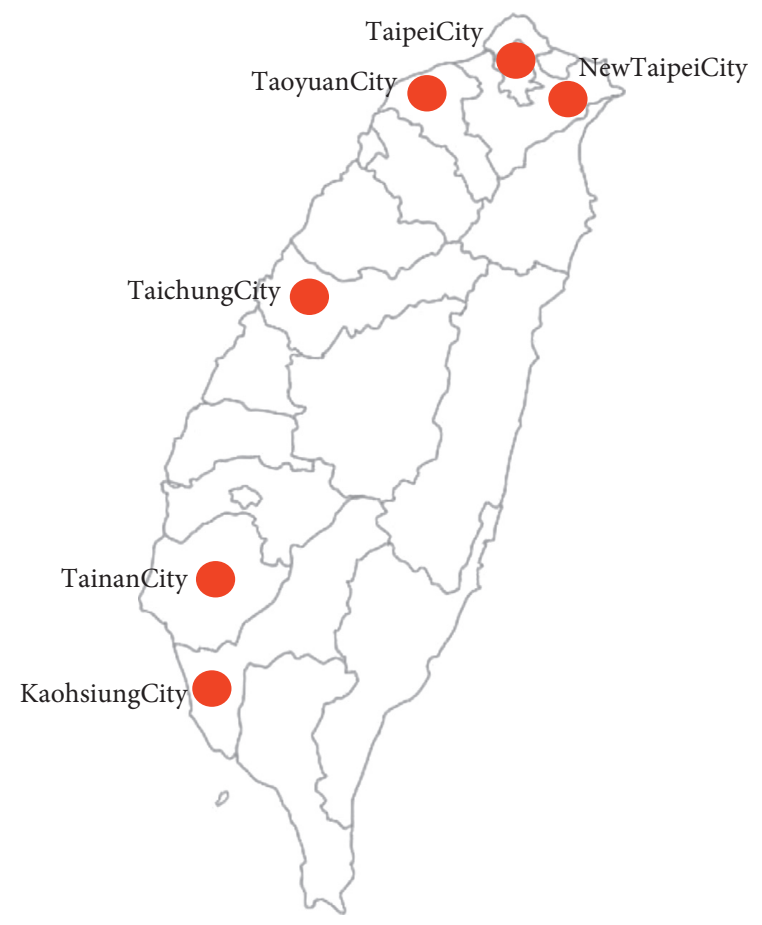

FIgURE 5: The locations of six municipalities in Taiwan.

were asked to answer their travel frequencies within a week in the past (prepandemic outbreak) and now (during the survey period).

3.3.3. Mode Choice. The questionnaire's mode choices include motorcycles, motorcycles (carried), cars, cars (carried), walking/bicycles, railway/light rails/mass rapid transit, buses, and taxis/carpooling. These options were classified into private transportation and transit by the type of use, among which transit was defined as a transport system with fixed routes, frequencies, stations, and fees. In summary, this item asked about weekly travel frequencies and travel characteristics.

Due to the influence of COVID-19 and government restrictions, it was impossible to collect paper data on a large scale in a short time. Thus, this study took Taiwan's Internet users as the respondents, and the online questionnaire was conducted on a governmental platform (The Ministry of Health and Welfare's Facebook Live channel), a school platform (National Chi Nan University's Facebook group), and a general public platform (Line groups) to collect information and investigate the influence of COVID-19 on the daily travel characteristics in Taiwan. The survey period was about 2 weeks, from April 22 to May 2, 2020. See Table 5 for details of the questionnaire.

\section{Data Analysis}

Figure 6 explains the data collection and analysis process of this study. First, the questionnaire was planned and designed, including three parts, and online questionnaire survey was conducted. After sorting out the collected data, 
TABle 5: Survey description.

\begin{tabular}{l} 
Survey classification \\
\hline \\
Survey on personal basic socioeconomic characteristics \\
$\begin{array}{l}\text { Part 1: Socioeconomic } \\
\text { characteristics: }\end{array}$ \\
Survey on household socioeconomic characteristics \\
(1) Travel purposes and frequencies \\
(2) Impact of employer's pandemic prevention measures \\
on travel changes
\end{tabular}

Part 2:

Travel characteristics:

Part 3:

Mode choice:
(3) Survey on changes in consumer behavior before and after the pandemic

(4) Survey on risk perceptions and perception attitudes regarding changes in travel behavior before and after the pandemic and related contingency measures

(1) Changes in means and frequency of transport before and after the pandemic
(1) Gender
(2) Age
(3) Occupation
(4) Place of residence
(5) Number of cars owned
(6) Number of motorcycles owned
(1) Monthly household income
(2) Number of family members or friends living at the place of residence

(3) Number of family members or friends under 18 living at the place of residence

(1) Difference in frequencies and purposes of travels per week

(2) Change of means/mode of commute

(1) Is working from home allowed by the employer?

(2) Is adjustment in pandemic prevention measures allowed by the employer, such as increasing the distance between work areas?

(1) Is there any change in the way of purchasing items, such as switching to online shopping?

(2) Will you stock on daily necessities?

(1) Degree of consent for impacts on changes in travel behavior

(2) Degree of acceptance of the government's pandemic control measures

(3) Survey on risk perceptions of travel behavior and health due to pandemic

(1) Motorcycles

(2) Motorcycles (carried)

(3) Cars

(4) Cars (carried)

(5) Walking/bicycles

(6) Railway/light rails/mass rapid transit

(7) Buses and taxis/carpooling

(8) Frequencies

(1) Motorcycles

(2) Motorcycles (carried)

(3) Cars

(4) Cars (carried)

(5) Walking/bicycles

(6) Railway/light rails/mass rapid transit

(7) Buses and taxis/carpooling

(1) Survey on behavior changes in domestic and foreign travel

(2) Purpose of air travel basic data analysis was performed, followed by model estimations, and discussions and suggested measures were proposed accordingly.

The sample size used in this study was calculated according to the following formula: sample size $=((\mathrm{Z}$-score $) \times$ StdDev $\times(1-$ StdDev $)) /[($ margin of error $) \rrbracket 2$. Assuming that we chose a 95\% confidence level, 0.5 standard deviation, and a margin of error (confidence interval) of $\pm 5 \%$, then the sample size is 385 . Therefore, the sample size of 387 in our study is sufficient statistically.

4.1. Socioeconomic Characteristics. According to the survey results shown in Table 6 , more women were surveyed than men, with a ratio of about 6 to 4 . In terms of age, people under 50 accounted for $92 \%$. The online questionnaire survey could not cover people in all age groups, because it is an on-line survey, some specific groups might not be covered, such as people who are not familiar with $3 \mathrm{C}$ products, including most of the elder people. Among which people between 18 and 24 accounted for $30.5 \%$. In terms of occupation, management staff, professionals, soldiers, public servants, and teachers were the main respondents, accounting for about $58 \%$. In terms of place of residence and work, respondents mainly lived in municipalities (Taipei City, New Taipei City, Taoyuan City, Taichung City, Tainan City, and Kaohsiung City), accounting for $76 \%$ and $73 \%$, respectively, which is in line with the population distribution in Taiwan. Those having monthly household incomes with 


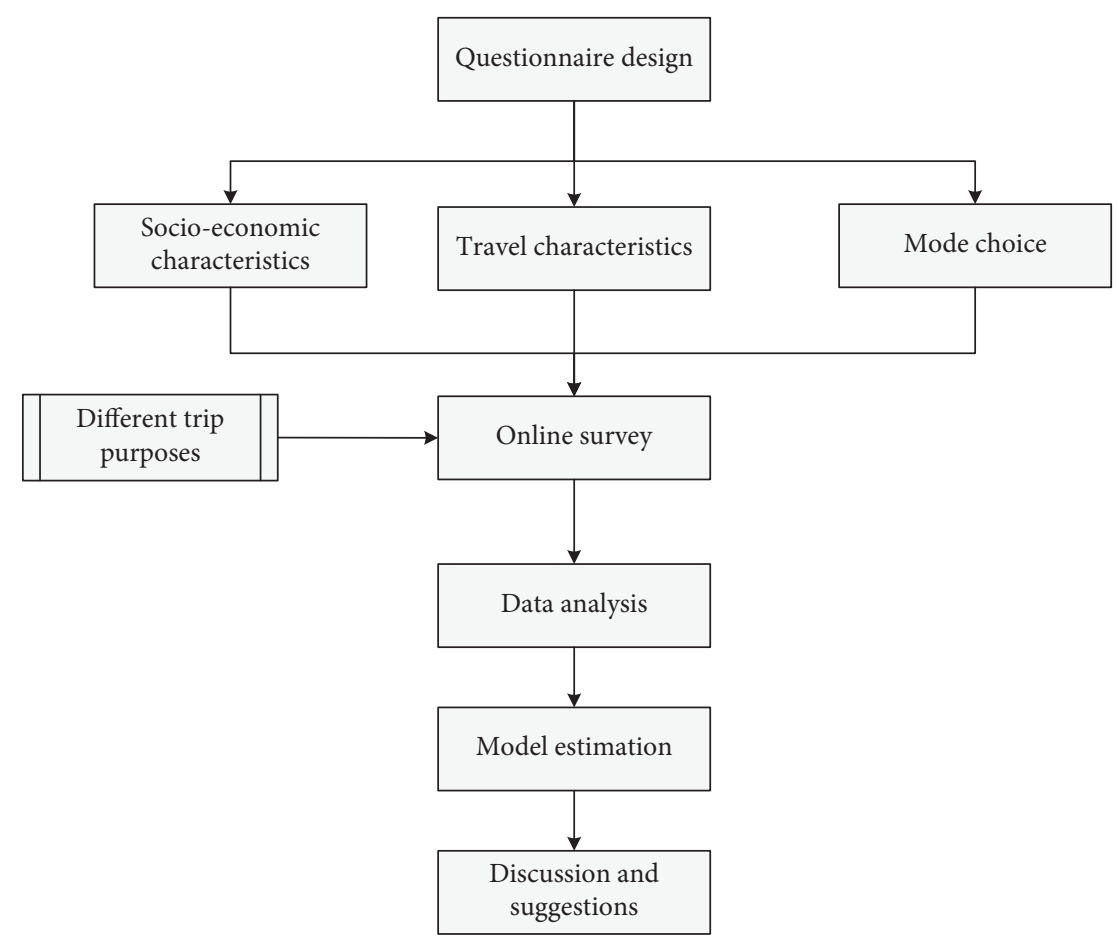

Figure 6: The data flow chart of this study.

TABLE 6: Analysis of socioeconomic characteristics.

\begin{tabular}{|c|c|c|c|}
\hline & & Total samples & Taiwan** \\
\hline \multirow{5}{*}{ Gender } & Male & $154(39.79 \%)$ & $11,673,765(49.55 \%)$ \\
\hline & Female & $233(60.21 \%)$ & $11,887,471(50.45 \%)$ \\
\hline & $18-24$ & $118(30.49 \%)$ & $1,996,738(10.01 \%)$ \\
\hline & $25-29$ & $73(18.86 \%)$ & $1,597,613(8.01 \%)$ \\
\hline & $30-34$ & $40(10.35 \%)$ & $1,583,943(7.94 \%)$ \\
\hline \multirow[t]{6}{*}{ Age } & $35-39$ & $43(11.11 \%)$ & $1,894,274(9.50 \%)$ \\
\hline & $40-44$ & $47(12.14 \%)$ & $2,016,609(10.11 \%)$ \\
\hline & $45-49$ & $35(9.04 \%)$ & $1,760,217(8.83 \%)$ \\
\hline & Above 50 years old & $31(8.01 \%)$ & $9,095,875(45.60 \%)$ \\
\hline & Management or administrative staff & $84(21.71 \%)$ & $3,967(23.70 \%)$ \\
\hline & Professionals & $85(21.96 \%)$ & $7,041(42.06 \%)$ \\
\hline \multirow[t]{6}{*}{ Occupation (thousand people) } & Soldiers, public servants, and teachers & $55(14.21 \%)$ & $1,024(6.12 \%)$ \\
\hline & Student & $110(28.42 \%)$ & $4,212(25.16 \%)$ \\
\hline & Others* & $53(13.70 \%)$ & $496(2.96 \%)$ \\
\hline & Taipei City & $57(14.73 \%)$ & $2,602,418(11.05 \%)$ \\
\hline & New Taipei City & $59(15.25 \%)$ & $4,030,954(17.11 \%)$ \\
\hline & Taoyuan City & $40(10.34 \%)$ & $2,268,807(9.63 \%)$ \\
\hline \multirow[t]{7}{*}{ Place of residence } & Taichung City & $80(20.67 \%)$ & $2,820,787(11.97 \%)$ \\
\hline & Tainan City & $26(6.72 \%)$ & $1,874,917(7.96 \%)$ \\
\hline & Kaohsiung City & $33(8.53 \%)$ & $2,765,932(11.74 \%)$ \\
\hline & Other counties and cities & $92(23.76 \%)$ & $7,197,421(30.54 \%)$ \\
\hline & Taipei City & $90(23.26 \%)$ & \\
\hline & New Taipei City & $25(6.46 \%)$ & \\
\hline & Taoyuan City & $40(10.34 \%)$ & \\
\hline \multirow[t]{4}{*}{ Place of work } & Taichung City & $73(18.86 \%)$ & - \\
\hline & Tainan City & $25(6.46 \%)$ & \\
\hline & Kaohsiung City & $31(8.01 \%)$ & \\
\hline & Other counties and cities & $103(26.61 \%)$ & \\
\hline
\end{tabular}


TABLE 6: Continued.

\begin{tabular}{|c|c|c|c|}
\hline Item & & Total samples & Taiwan** \\
\hline \multirow{6}{*}{ Monthly household income } & Less than NTD 50,000 & $111(28.68 \%)$ & - \\
\hline & NTD 50,001-75,000 & $85(21.96 \%)$ & \\
\hline & NTD 75,001-100,000 & $50(12.92 \%)$ & \\
\hline & NTD $100,001-125,000$ & $44(11.37 \%)$ & \\
\hline & NTD $125,001-175,000$ & $49(12.67 \%)$ & \\
\hline & More than NTD 175,001 & $48(12.40 \%)$ & \\
\hline \multirow{4}{*}{ Number of cars owned } & 0 vehicle & $79(20.41 \%)$ & $81,932(1 \%)$ \\
\hline & 1 vehicle & $167(43.15 \%)$ & $4,883,169(59.6 \%)$ \\
\hline & 2 vehicles & $106(27.39 \%)$ & $2,433,391(29.7 \%)$ \\
\hline & More than 3 vehicles & $35(9.05 \%)$ & $794,743(9.7 \%)$ \\
\hline \multirow{5}{*}{ Number of motorcycles owned } & 0 vehicle & $62(16.02 \%)$ & $1,720,659(12.2 \%)$ \\
\hline & 1 vehicle & $103(26.61 \%)$ & $5,303,014(37.6 \%)$ \\
\hline & 2 vehicles & $89(23.00 \%)$ & $3,977,261(28.2 \%)$ \\
\hline & 3 vehicles & $71(18.35 \%)$ & $3,116,931(22.1 \%)$ \\
\hline & More than 4 vehicles & $62(16.02 \%)$ & $1,720,659(12.2 \%)$ \\
\hline \multirow{6}{*}{ Number of household members (including oneself) } & 1 person & $57(14.73 \%)$ & $3,041,975(34.05 \%)$ \\
\hline & 2 persons & $52(13.44 \%)$ & $1,833,256(20.52 \%)$ \\
\hline & 3 persons & $54(13.95 \%)$ & $1,619,929(18.13 \%)$ \\
\hline & 4 persons & $86(22.22 \%)$ & $1,298,969(14.54 \%)$ \\
\hline & 5 persons & $50(12.92 \%)$ & $592,634(6.63 \%)$ \\
\hline & More than 6 persons ${ }^{* * *}$ & $88(22.74 \%)$ & $546,523(6.12 \%)$ \\
\hline Number of household members under 18 & 0 person & $255(65.89 \%)$ & - \\
\hline
\end{tabular}

${ }^{*}$ indicates that those occupations not described in the options are included in others. ${ }^{* *}$ Source: National Statistics, R.O.C (Taiwan). https://www.stat.gov.tw/ np.asp?ctNode546. ${ }^{* * *}$ indicates that, for students renting houses off-campus (student dormitories), those living together are included in the household members.

less than NTD 75,000 accounted for 51\%, whereas those with monthly household incomes of more than NTD 175,001 accounted for $12.4 \%$. In terms of the number of cars owned, those without cars accounted for about $20 \%$, and those with 1 to 2 cars accounted for about $71 \%$. In terms of the number of motorcycles owned, those without motorcycles accounted for about $16 \%$, and those with 1 to 2 motorcycles accounted for about $50 \%$. In terms of members living, about $15 \%$ lived alone; about $50 \%$ lived with 2 to 4 people (including themselves); $66 \%$ did not live with someone under $18 ; 34 \%$ lived with more than 2 people under 18 .

4.2. Travel Characteristics. According to the survey data's preliminary analysis results shown in Table 7, the number of travels for almost all purposes has decreased compared to the past. Comparing past and present situations, the average weekly travel for social contact/recreation among nonroutine travels decreased by 0.58 (from 3.53 to 2.95), the highest among all travel purposes. This is followed by purchasing consumer goods in routine travels, with the average weekly travel decreasing by 0.51 (from 3.75 to 3.24 ). On the other hand, for routine travels, business travels slightly increased by 0.01 (from 3.45 to 3.46 ), the only increase of all travel purposes. The results show that, due to the influence of the COVID-19 pandemic, people might first reduce nonroutine travels, such as social entertainment. This study tested and compared past and present situations to discuss further COVID-19's influence on different travel purposes. The results are shown in Table 7 . According to the results, both routine travels and nonroutine travels are significantly reduced compared to the past. Such reduction includes a
TABle 7: Test of travel purposes.

\begin{tabular}{|c|c|c|c|c|}
\hline \multicolumn{2}{|c|}{$\begin{array}{l}\text { Travel purposes/average number of } \\
\text { travels/person-week }\end{array}$} & Past & Present & $T$-values \\
\hline \multirow{4}{*}{ Routine } & Commute & 4.42 & 4.20 & 0.65 \\
\hline & Going to school & 4.86 & 4.67 & 0.35 \\
\hline & Parenting & 3.25 & 2.80 & 0.81 \\
\hline & $\begin{array}{c}\text { Purchasing consumer } \\
\text { goods }\end{array}$ & 3.75 & 3.24 & $2.28^{*}$ \\
\hline \multicolumn{2}{|c|}{ Total routine travels } & 8.07 & 7.39 & $1.85^{*}$ \\
\hline \multirow{3}{*}{ Nonroutine } & Business & 3.45 & 3.46 & -0.01 \\
\hline & Shopping & 2.85 & 2.70 & 0.54 \\
\hline & Personal affairs & 3.44 & 3.09 & 1.41 \\
\hline \multirow{2}{*}{\multicolumn{2}{|c|}{$\begin{array}{l}\text { Social contact/recreation } \\
\text { Total nonroutine travels }\end{array}$}} & 3.53 & 2.95 & $2.15^{*}$ \\
\hline & & 7.30 & 6.03 & $3.02^{*}$ \\
\hline
\end{tabular}

significant decrease in purchasing consumer goods in routine travels, indicating that people might consider the high infection rate of COVID-19 coupled with government advocacy and decrease their travels to reduce exposure in public places, such as stores. Regarding nonroutine travels, which are unnecessary, decreased travel for social contact/ entertainment was the most significant.

4.3. Mode Choice. According to the survey data's preliminary analysis results shown in Table 8 , travel by all modes is decreased compared to the past. By comparing past and present situations, the average weekly travel by motorcycle decreased by 1.6 (from 10.70 to 9.10), the largest among all vehicles. This is followed by cars, with the average weekly travel decreasing by 1.6 (from 8.50 to 7.48 ). The weekly travels by bus decreased by 0.24 (from 5.46 to 5.22 ), the smallest among all vehicles. 
TABLE 8: Test of mode choice.

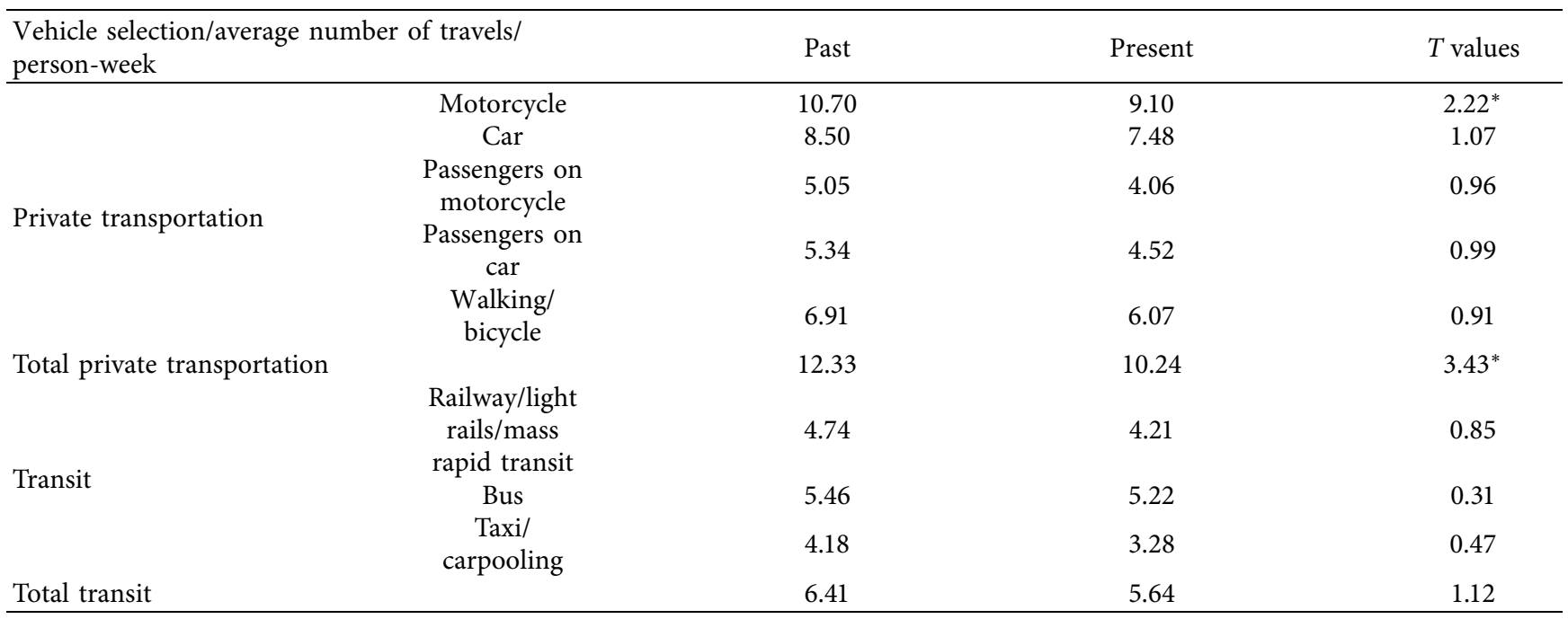

*indicates a significant level above $10 \%$.

This study tested past and present situations to discuss further the influence on mode choice. The results are shown in Table 8. According to the results, the total travels by private vehicles significantly reduced, with the most significant decrease of about 1.6 per week in travels by motorcycle, which is possibly a result of people's concern over being infected when driving a motorcycle (droplet infection could not be prevented during parking or driving). Furthermore, there was a significant reduction because motorcycles were convenient for social/entertainment travels or nonroutine travels. However, the difference in transit use is marginal, possibly because transit users were left with no choice (captive riders).

\section{Model Estimation Results}

\subsection{Logistic Regression Model}

5.1.1. Changes in the Total Number of Travels (Model 1). This study first used logistic regression models to investigate the important variables regarding decreased travels (compared with the past and the present, the decrease was 1 , while maintaining was 0 ) after the large-scale global outbreak. The model estimation results are shown in Table 9. Notably, the model has good convergence. The explanatory variables found that people traveled significantly less after the government's policy to implement the real-name registration system for mask purchases, possibly because they felt the severity of the pandemic. Based on the discussion on the types of weekly activities and the number of necessary activities, people who had more types of weekly activities traveled significantly less, which may have resulted from a reduction of some unnecessary activities. Furthermore, as defined in this study, the routine weekly activities include commuting, going to school, parenting, and purchasing consumer goods. It was found that the more travels that could not be replaced by other modes, the less likely people were to reduce such travels. This finding indicates that nonroutine travels in life, such as social, sports, or artistic activities, were most influenced by special events. The more people agree with the central government's emergency measures for the pandemic-such as advocating reduced travels to public places, wearing masks when entering and leaving MRT (mass rapid transit) stations, or taking transit-the more appropriate they consider the central government's emergency measures and the more likely they are to follow them and reduce travels. People who stored more types of consumer goods might not need to go out frequently to buy; hence, they traveled significantly less. Moreover, after the first case was confirmed, people who were highly concerned about the hygienic conditions of transit (such as carriage disinfection) significantly reduced their travels. This variable indicates that people would pay special attention to public places, where close contacts were more likely to happen, and social distancing was harder to maintain, which might reduce their exposure.

5.1.2. Changes in Travels by Private Vehicles (Model 2). Based on the basic analysis, since there was a significant difference in the travel changes by private vehicles, this study further established a model to investigate the important influencing factors. As shown in Table 9, the significant variables are the reduced overall number of travels and the significant reduction of travel by private vehicles after the policy of the real-name registration system for mask purchases. These variables indicate that people cooperated with the policy and paid attention to their health and, thus, reduced their travels. People who have more types of weekly activities tended to reduce travels by private vehicles. On the other hand, people who had more necessary routine weekly activities (commuting, picking up children) were less likely to reduce travels by private vehicles, possibly because traveling by private vehicles could ensure a clean environment and reduce the risk of infection. People who worked more days a week and could not reduce necessary travels 
TABLE 9: Estimation results of logistic regression models.

\begin{tabular}{|c|c|c|c|}
\hline Explanatory variables & Model 1 & Model 2 & Model 3 \\
\hline Constant terms & $\begin{array}{l}-4.97 \\
(-5.06)^{* * *}\end{array}$ & $\begin{array}{l}-1.89 \\
(-2.12)^{* * *}\end{array}$ & $-5.45(-6.32)^{* * *}$ \\
\hline Time_real-name registration system for mask purchases & $0.97(3.02)^{* * *}$ & $0.82(2.39)^{* * *}$ & $0.74(2.07)^{* * *}$ \\
\hline Types of weekly activities & $0.17(3.08)^{* * *}$ & $0.12(2.10)^{* * *}$ & $0.19(3.28)^{* * *}$ \\
\hline Number of routine activities per week & $\begin{array}{c}-1.21 \\
(-6.88)^{* * *}\end{array}$ & $\begin{array}{l}-0.51 \\
(-6.48)^{* * *}\end{array}$ & - \\
\hline Reduction of the use of private vehicles (comparison between the present and the past) & - & - & $-0.46(-6.95)^{* * *}$ \\
\hline $\begin{array}{l}\text { Employers' emergency measures (people are required to work from home in the future } \\
\text { due to the pandemic) }\end{array}$ & - & - & $0.76(2.3)^{* * *}$ \\
\hline $\begin{array}{l}\text { Emergency measures of the central government to the pandemic are considered } \\
\text { appropriate }\end{array}$ & $0.24(1.29)^{*}$ & - & - \\
\hline Number of working days per week & - & $\begin{array}{l}-0.55 \\
(-3.74)^{* * *}\end{array}$ & - \\
\hline Types of consumer goods stored & $0.19(2.51)^{* * *}$ & $0.22(2.8)^{* * *}$ & $0.14(1.72)^{* *}$ \\
\hline $\begin{array}{l}\text { Before confirmation of the first case-attention to the hygienic conditions of transit } \\
\text { (such as carriage disinfection) }\end{array}$ & $0.29(2.05)^{* * *}$ & $0.36(2.36)^{* * *}$ & $0.60(3.61)^{* * *}$ \\
\hline $\begin{array}{l}\text { After confirmation of the first case-attention to the hygienic conditions of transit } \\
\text { (such as carriage disinfection) }\end{array}$ & - & - & $-0.39(-2.81)^{* * *}$ \\
\hline Living and working in different counties or cities & - & - & $0.96(2.38)^{* * *}$ \\
\hline Pseudo $R^{2}$ & 0.36 & 0.29 & 0.36 \\
\hline Sample size & & 387 & \\
\hline
\end{tabular}

${ }^{* * *}$ indicates a significant level of $5 \%{ }^{* *}$ indicates a significant level of $10 \% ;{ }^{*}$ indicates a significant level above $10 \%$.

were less likely to reduce travels by private vehicles. Such finding is consistent with prior knowledge, which means that as private vehicles carried fewer people, passengers' physical conditions and hygienic conditions in cars (disinfection) were more satisfactory to the users' expectations. Storage of more types of consumer goods implies lower demand for purchasing, thereby reducing the use of private vehicles. People who were highly concerned about the hygienic conditions of transit after the first case was confirmed were more likely to reduce travels by private vehicles, possibly because they are sensitive to their living environment; hence, they reduce their travels.

5.1.3. Changes in Nonroutine Travels (Model 3). According to statistical testing, nonroutine travels changed the most among the travel characteristics, with a decrease of about 1.3 per week. Logistic regression was also used in further exploration to investigate the important influencing factors. The estimation results are shown in Table 9. The important influencing factors include the real-name registration system for mask purchases, types of weekly activities, storage of consumer goods, and attention to the hygienic conditions of transit after the first case was confirmed. Moreover, people who reduced their use of private vehicles were less likely to reduce nonroutine travels, possibly because transit was less convenient for nonroutine travels, including social entertainment or shopping. The emergency measures of employers (i.e., required work-from-home arrangements) also reduced nonroutine travels, possibly because business travels are considered part of nonroutine travels and were canceled once people worked from home. In terms of attention to the hygienic conditions of transit, while people did not reduce nonroutine travels before the first case was confirmed, they tended to reduce nonroutine travels after.
This finding is consistent with prior knowledge, where people are less likely to travel unnecessarily when they are worried about being infected. Finally, people who work and live in different counties or cities might be exposed to public places for a longer time, which implies their higher probability of infection. Thus, they reduced nonroutine travels to ensure safety.

5.1.4. Odd Ratios. To understand the influence of the various important variables in all models on travel reduction, the odds ratios (the ratio between the probability of travel reduction and the probability of travel constancy) of all variables were further calculated in this study by (2). The results are shown in Table 10. Based on the table, the influence of the government's real-name registration system for mask purchases is the greatest in Models 1 and 2, with the odds ratios of 2.679 and 2.276, respectively. Meanwhile, the influence of this variable is also significant in Model 3 (with an odds ratio of 2.099). In other words, for the 3 models, after the government's real-name registration system for mask purchases, the probability of travel reduction is more than twice as high as the probability of travel constancy. Regarding the other 2 variables in Model 3 (i.e., employers' emergency measures and living and working in different counties or cities), the probability of travel reduction is also more than twice as high as the probability of travel constancy. The odds ratios of the 3 variables-types of weekly activities, types of consumer goods stored, and attention to the hygienic conditions of transit after confirmation of the first case-are between 1.10 and 1.83 ; that is, the probability of travel reduction is one to two times the probability of travel constancy. The odds ratios of the number of routine activities per week in Model 1 and Model 2 are smaller than 1 , indicating that the probability of travel reduction is $29.9 \%$ 
TABLE 10: Odds ratios of logistic regression models.

\begin{tabular}{|c|c|c|c|}
\hline Explanatory variables & Model 1 & Model 2 & Model 3 \\
\hline Constant terms & 0.01 & 0.15 & 0.01 \\
\hline Time_real-name registration system for mask purchases & 2.68 & 2.27 & 2.10 \\
\hline Types of weekly activities & 1.18 & 1.13 & 1.22 \\
\hline Number of routine activities per week & 0.30 & 0.60 & - \\
\hline Reduction of the use of private vehicles (comparison between the present and the past) & - & - & 0.63 \\
\hline Employers' emergency measures (people are required to work from home in the future due to the pandemic) & - & - & 2.15 \\
\hline Emergency measures of the central government to the pandemic are considered appropriate & 1.27 & - & - \\
\hline Number of working days per week & - & 0.58 & - \\
\hline Types of consumer goods stored & 1.21 & 1.24 & 1,14 \\
\hline $\begin{array}{l}\text { After confirmation of the first case-attention to the hygienic conditions of transit (such as carriage } \\
\text { disinfection) }\end{array}$ & 1.34 & 1.43 & 1.83 \\
\hline $\begin{array}{l}\text { Before confirmation of the first case-attention to the hygienic conditions of transit (such as carriage } \\
\text { disinfection) }\end{array}$ & - & - & 0.68 \\
\hline Living and working in different counties or cities & - & - & 2.60 \\
\hline
\end{tabular}

*** indicates a significant level of $5 \%$; ${ }^{* *}$ indicates a significant level of $10 \% ;{ }^{*}$ indicates a significant level above $10 \%$.

TABLE 11: Estimation results of ordered logit models.

\begin{tabular}{|c|c|c|c|}
\hline Explanatory variables & Model 1 & Model 2 & Model 3 \\
\hline Time_real-name registration system for mask purchases & $0.89(2.99)^{* * *}$ & $0.78(2.39)^{* * *}$ & $0.61(2.05)^{* * *}$ \\
\hline Types of weekly activities & $0.14(2.97)^{* * *}$ & $0.11(2.09)^{* * *}$ & $0.14(2.86)^{* * *}$ \\
\hline Reduction of the use of private vehicles (comparison between the present and the past) & - & - & $\begin{array}{c}-0.34 \\
(-8.31)^{* * *}\end{array}$ \\
\hline $\begin{array}{l}\text { Employers' emergency measures (people are required to work from home in the future } \\
\text { due to the pandemic) }\end{array}$ & - & - & $0.33(1.14)^{*}$ \\
\hline Number of routine activities per week & $\begin{array}{l}-0.96 \\
(-9.41)^{* * *}\end{array}$ & $\begin{array}{l}-0.44 \\
(-7.44)^{* * *}\end{array}$ & - \\
\hline Number of working days per week & - & $\begin{array}{l}-0.51 \\
(-3.79)^{* * *}\end{array}$ & - \\
\hline $\begin{array}{l}\text { Emergency measures of the central government to the pandemic are considered } \\
\text { appropriate }\end{array}$ & $0.23(1.36)^{*}$ & - & - \\
\hline Types of consumer goods stored & $0.19(2.79)^{* * *}$ & $0.23(3.13)^{* * *}$ & $0.10(1.44)^{*}$ \\
\hline $\begin{array}{l}\text { After a positive case is confirmed-attention to the hygienic conditions of transit (such } \\
\text { as carriage disinfection) }\end{array}$ & $0.28(2.08)^{* * *}$ & $0.36(2.48)^{* * *}$ & $0.38(2.64)^{* * *}$ \\
\hline $\begin{array}{l}\text { Before confirmation of the first case-attention to the hygienic conditions of transit } \\
\text { (such as carriage disinfection) }\end{array}$ & - & - & $\begin{array}{l}-0.26 \\
(-2.17)^{* * *}\end{array}$ \\
\hline Living and working in different counties or cities & - & - & $0.586(1.80)^{* *}$ \\
\hline Threshold 1 & $4.67(5.25)$ & $1.95(2.30)$ & $3.95(5.66)$ \\
\hline Threshold 2 & $7.07(7.38)$ & $3.50(4.02)$ & $6.83(8.61)$ \\
\hline Pseudo R2 & 0.34 & 0.24 & 0.28 \\
\hline Simple size & & 387 & \\
\hline
\end{tabular}

${ }^{* * *}$ indicates a significant level of $5 \%$; ${ }^{* *}$ indicates a significant level of $10 \%$; ${ }^{*}$ indicates a significant level above $10 \%$.

and $59.9 \%$ of the probability of travel constancy, respectively. In Model 3, the odds ratio of the reduced use of private vehicles is 0.629 , indicating that people are less likely to reduce nonroutine travels. See Sections 5.1 to 5.3 for explanations of the reasons, which are not explained here.

5.2. Ordered Logit Model. The influence on travel reduction (number of occurrences) was further investigated by the ordered logit models. See Section 3 for the order level switching in the models. The estimation results and odds ratios are shown in Tables 11 and 12. The significant changes are consistent with logistic regression, indicating that these factors influence travel reduction at different levels. As the estimated thresholds are significantly positive, it is appropriate to classify travel reduction. For the same variable, the coefficient of the ordered model is smaller than that of the logit model, indicating that the influence of the coefficient would be overestimated if dichotomous data had been taken as the dependent variables. While the Pseudo $R^{2}$ of the ordered logit model is slightly smaller, it is not different from that of the logistic model; hence, this study suggests that the ordered logit models can explain the influence of COVID-19 on travel behaviors in Taiwan.

5.3. Discussion of Results. In terms of the models, as the estimated thresholds are significantly positive, it is appropriate to classify travel reduction. For the same variable, the coefficient of the ordered model is smaller than that of the logit model, indicating that the influence of the coefficient would be overestimated if dichotomous data had been taken 
TABLE 12: Odds ratio of ordered logit models.

\begin{tabular}{|c|c|c|c|}
\hline Explanatory variables & Model 1 & Model 2 & Model 3 \\
\hline Time_real-name registration system for mask purchases & 2.42 & 2.18 & 1.15 \\
\hline Types of weekly activities & 1.16 & 1.12 & 1.85 \\
\hline Number of routine activities per week & 0.38 & 0.64 & \\
\hline Reduction of the use of private vehicles (comparison between the present and the past) & - & - & 0.71 \\
\hline Employers' emergency measures (people are required to work from home in the future due to the pandemic) & - & - & 1.39 \\
\hline Emergency measures of the central government to the pandemic are considered appropriate & 1.26 & - & - \\
\hline Number of working days per week & - & 0.58 & - \\
\hline Types of consumer goods stored & 1.21 & 1.26 & 1.11 \\
\hline $\begin{array}{l}\text { After a positive case is confirmed-attention to the hygienic conditions of transit (such as carriage } \\
\text { disinfection) }\end{array}$ & 1.32 & 1.43 & 1.47 \\
\hline $\begin{array}{l}\text { Before confirmation of the first case-attention to the hygienic conditions of transit (such as carriage } \\
\text { disinfection) }\end{array}$ & - & - & 0.77 \\
\hline Living and working in different counties or cities & - & - & 1.80 \\
\hline
\end{tabular}

*** indicates a significant level of $5 \%{ }^{* *}$ indicates a significant level of $10 \% ;{ }^{*}$ indicates a significant level above $10 \%$.

as the dependent variables. While the Pseudo $R^{2}$ of the ordered logit model is slightly smaller, it is not different from that of the logistic model. Thus, this study suggests that the influence of COVID-19 on travel behaviors in Taiwan can be explained by the ordered logit models.

The important findings are as follows: (1) due to the influence of the pandemic, people might significantly reduce travels related to social entertainment. (2) In terms of vehicle selection, the total travels by private vehicles are significantly reduced, while there is no significant decrease in the use of transit, possibly because transit users have no choice. (3) The important explanatory variables include the importance of the time to promote government policies, the types and number of weekly activities, and the storage of various types of consumer goods. Government policies include implementing the real-name registration system for mask purchases, publishing confirmed cases, and establishing the transit disinfection system. (4) According to the comparison between Taiwan and Australia, the characteristics of the use of private vehicles (self-used vehicles) are similar. People will reduce their use of private vehicles in the face of special conditions (large scale, rapid infection, and serious harm), possibly because they are required to work from home to follow employers' emergency measures or reduce travels to ensure safety (avoid being infected). In addition, this study reached the same result as that of Beck and Hensher [5] where both socioeconomic characteristics and demographic characteristics are found insignificant in the models.

\section{Conclusions and Suggestions}

As COVID-19 has not yet been controlled while it has significantly influenced people's travel behaviors worldwide, this study conducted an in-depth investigation of the changes in people's travel behaviors after the outbreak through a questionnaire survey. However, online questionnaires were used for data collection, considering the government's control strategies and health concerns. In the process of analysis, the future development trend of COVID-19 is not clear. As the number of infected people in countries around the world continues to rise, people cannot yet understand or evaluate the future development trend.
Hence, this study investigated and analyzed the changes in current daily travel behaviors (during the survey period) compared with the past (prepandemic outbreak).

In the increasingly severe COVID-19 pandemic, effectively reducing people's frequency of travel is the key to curbing the rapid spread of COVID-19. This study classified and assessed the types of changes in the frequency of people's travel during the pandemic period. Furthermore, it concluded that the implementation of some measures could effectively reduce the frequency of travel. Therefore, this study proposed the following suggestions for different stakeholders. (1) For the central government, the real-name system for purchasing masks should be implemented as soon as possible, which can effectively allocate mask resources to the people in need, accelerate the coverage of overall mask protection, and effectively curb the pandemic. (2) For the local authority, it is advised to advocate that the types of people's weekly activities should be restricted or even forbidden, and related activities should be prohibited for outdoor public spaces to reduce the demand for people to go out. (3) For the general public, with people's usual routine activities, it is advised that restrictions or crowd control should be implemented, and the diversion of people flow or shifts should be adopted to minimize the frequency of weekly routine activities. These activities include traditional market purchases, shopping mall purchases, fixed weekly classes (such as workplace training and gym), even daily school schedules for students, and work schedules for workers. (4) For the environment, regular and quantitative environmental disinfection should be implemented for the public transportation system, including important public transportation stations, such as the high-speed rail, the MRT, and bus stations.

Finally, limited by the short survey period and considering investigators' health and people's rejection of face-toface interviews, online questionnaires were used in this study for data collection. Thus, the obtained data might not conform to the sampling theory. However, the preliminary findings of this study still help provide a conceptual review of how Taiwan deals with the severe influence of pandemics. On the other hand, the increase or decrease in the number of travels might have a relationship with the number of 
vaccines administered; however, the vaccines were not available until March 3, 2021. Therefore, the effects of vaccines on travels were not investigated since the data that could be obtained were not enough.

\section{Data Availability}

The data used to support the findings of this study are available from the corresponding author upon request.

\section{Conflicts of Interest}

The authors declare that they have no conflicts of interest.

\section{References}

[1] C. S. Chiu, R. C. Jou, Y. H. Liu et al., "Research on the Impact of SARS on Travelers' Travel Behavior," in Proceedings of the International Conference of Chinese Institute of Transportation, Vancouver, Canada, December 2003.

[2] Ö. Kaya, A. Tortum, K. D. Alemdar, and M. Y. Çodur, "Site selection for EVCS in Istanbul by GIS and multi-criteria decision-making," Transportation Research Part D: Transport and Environment, vol. 80, Article ID 102271, 2020.

[3] Ö. Kaya, K. D. Alemdar, T. Campisi, A. Tortum, and M. K. Çodur, "The development of decarbonisation strategies: a three-step methodology for the suitable analysis of current EVCS locations applied to Istanbul, Turkey," Energies, vol. 14, no. 10, p. 2756, 2021.

[4] "Taiwan Centers for Disease Control," 2020, https://nidss.cdc. gov.tw/.

[5] M. J. Beck and D. A. Hensher, "Insights into the impact of COVID-19 on household travel and activities in Australia-the early days under restrictions," Transport Policy, vol. 96, pp. 76-93, 2020.

[6] J. Stanley, J. Stanley, C. Balbontin, and D. Hensher, "Social exclusion: the roles of mobility and bridging social capital in regional Australia," Transportation Research Part A, vol. 125, pp. 223-233, 2019.

[7] J. Stanley, D. A. Hensher, J. Stanley, G. Currie, W. H. Greene, and D. Vella-Brodrick, "Social exclusion and the value of mobility," Journal of Transport Economics and Policy, vol. 45, no. 2, pp. 197-222, 2011.

[8] J. K. Stanley, D. A. Hensher, J. Stanley, and D. Vella-Brodrick, "Mobility, social exclusion and wellbeing: exploring the links," Transportation Research Part A, vol. 45, pp. 789-801, 2011.

[9] C. J. Bergstad, A. Gamble, T. Garling et al., "Subjective wellbeing related to satisfaction with daily travel," Transportation, vol. 38, pp. 1-15, 2011.

[10] A. Graham, F. Kremarik, and W. Kruse, "Attitudes of ageing passengers to air travel since the coronavirus pandemic," Journal of Air Transport Management, vol. 87, Article ID 101865, 2020.

[11] J. De Vos, "The effect of COVID-19 and subsequent social distancing on travel behavior," Transportation Research Interdisciplinary Perspectives, vol. 5, Article ID 100121, 2020.

[12] R. Zheng, Y. Xu, W. Wang, G. Ning, and Y. Bi, "Spatial transmission of Covid-19 via public and private transportation in China," Travel Medicine and Infectious Disease, vol. 34, Article ID 101626, 2020.

[13] J. T. Wu, K. Leung, and G. M. Leung, "Nowcasting and forecasting the potential domestic and international spread of the 2019-nCoV outbreak originating in Wuhan, China: a modelling study," The Lancet, vol. 395, no. 10225, pp. 689-697, 2020.

[14] C. Musselwhite, E. Avineri, and Y. Susilo, "Editorial JTH 16 -The Coronavirus Disease COVID-19 and implications for transport and health," Journal of Transport \& Health, vol. 16, Article ID 100853, 2020.

[15] H. Lau, V. Khosrawipour, P. Kocbach et al., "The association between international and domestic air traffic and the coronavirus (COVID-19) outbreak," Journal of Microbiology, Immunology, and Infection, vol. 53, no. 3, 2020.

[16] H. Dong, S. Ma, N. Jia, and J. Tian, "Understanding public transport satisfaction in post COVID-19 pandemic," Transport Policy, vol. 101, pp. 81-88, 2021.

[17] T. Campisia, S. Basbasb, M. A. Al-Rashidc, G. Tesorierea, and G. Georgiadisd, "A region-wide survey on emotional and psychological impacts of COVID-19 on public transport choices in Sicily, Italy," Transactions on Transport Sciences, vol. 2, 2021.

[18] R. Vickerman, "Will COVID-19 put the public back in public transport? A UK perspective," Transport Policy, vol. 103, pp. 95-102, 2021.

[19] H.-H. Chang, C. D. Meyerhoefer, and F.-A. Yang, "COVID-19 prevention, air pollution and transportation patterns in the absence of a lockdown," Journal of Environmental Management, vol. 298, Article ID 113522, 2021.

[20] M. Cusack, "Individual, social, and environmental factors associated with active transportation commuting during the COVID-19 pandemic," Journal of Transport \& Health, vol. 22, Article ID 101089, 2021.

[21] L. A. W. Fumagalli, D. A. Rezende, and T. A. Guimarães, "Challenges for public transportation: consequences and possible alternatives for the Covid-19 pandemic through strategic digital city application," Journal of Urban Management, vol. 10, no. 2, pp. 97-109, 2021.

[22] V. Padmanabhan, P. Penmetsa, X. Li, F. Dhondia, S. Dhondia, and A. Parrish, "COVID-19 effects on shared-biking in New York, Boston, and Chicago," Transportation Research Interdisciplinary Perspectives, vol. 9, Article ID 100282, 2021.

[23] S. Shakibaei, G. C. De Jong, P. Alpkökin, and T. H. Rashidi, "Impact of the COVID-19 pandemic on travel behavior in Istanbul: a panel data analysis," Sustainable Cities and Society, vol. 65, Article ID 102619, 2021.

[24] C. Eisenmann, C. Nobis, V. Kolarova, B. Lenz, and C. Winkler, "Transport mode use during the COVID-19 lockdown period in Germany: the car became more important, public transport lost ground," Transport Policy, vol. 103, pp. 60-67, 2021.

[25] S. Awad-Núñez, R. Julio, B. Moya-Gómez, J. Gomez, and J. Sastre González, "Acceptability of sustainable mobility policies under a post-COVID-19 scenario. Evidence from Spain,” Transport Policy, vol. 106, pp. 205-214, 2021.

[26] M. Scorrano and R. Danielis, "Active mobility in an Italian city: mode choice determinants and attitudes before and during the Covid-19 emergency," Research in Transportation Economics, vol. 86, Article ID 101031, 2021.

[27] E. Elldér, "Telework and daily travel: new evidence from Sweden," Journal of Transport Geography, vol. 86, Article ID 102777, 2020. 